\title{
The Structure and Acetylene-reducing Activity of Root Nodules Formed by a Riboflavin-requiring Mutant of Rhizobium trifolii
}

\author{
By C. E. PANKHURST \\ Botany Department, Australian National University, Canberra, Australia \\ E. A. SCHWINGHAMER AND F. J. BERGERSEN \\ Division of Plant Industry, CSIRO, Canberra, Australia
}

(Accepted for publication 2 October I97I)

SUMMARY

Root nodules formed by a riboflavin-requiring auxotroph of Rhizobium trifolii (TI/D-his ${ }^{r}$-I5) on red clover (Trifolium pratense L.) seedlings grown with or without added riboflavin, showed changes in structure or acetylene-reducing activity when compared with effective nodules produced by the parent strain (TI). Additional riboflavin was essential for the conversion of vegetative bacteria of the mutant strain into functional, $\mathrm{N}_{2}$-fixing bacteroids within the nodules. If riboflavin was not added to the plants, a large proportion of the rhizobia in the host cells failed to develop, and the nodules were almost ineffective, reducing acetylene at a very low rate. When riboflavin was added to the plant growth medium, even as late as 8 days after inoculation, most mutant rhizobia survived and continued to develop into normal bacteroids. This requirement for riboflavin was most critical I to 3 days after the appearance of the nodules (about 7 to 9 days after inoculation). If the auxotroph was sustained through this period with added riboflavin, the vitamin could then be removed from the plant substrate and the nodules continued to develop effectively. Impairment in the release of rhizobia from infection threads was observed in older nodules formed by TI/D-his ${ }^{\mathrm{r}}-\mathrm{I}_{5}$ in the absence of riboflavin, the rhizobia becoming enveloped in large masses of polysaccharide-like material within the host cells.

\section{INTRODUCTION}

The establishment of a normal symbiosis between a strain of Rhizobium and its legume host involves complex physiological and biochemical interactions which are not well understood. Considerable attention has been directed to interactions occurring at the roothair surface where compatible strains of rhizobia invade the hair and produce an infection thread (Fahraeus \& Ljunggren, I968; Yao \& Vincent, I968; Roughley, Dart \& Nutman, 1970). Less is known of interactions which occur in the subsequent stages of nodule development, particularly when the rhizobia are released from the infection thread into the host cell, and change from vegetative rods into $\mathrm{N}_{2}$-fixing bacteroids. Biochemical studies of isolated bacteroids (Appleby \& Bergersen, 1958; Fottrell, 1966; Appleby, 1967; Moustafa \& Greenwood, 1967 , and others) indicate that, in addition to the synthesis of nitrogenase, many other metabolic events accompany bacteroid formation. Such changes have also been studied by observation of the fine structure of developing bacteroids (Bergersen \& Briggs, 1958; Dart \& Mercer, 1963, 1964; Mosse, 1964; Goodchild \& Bergersen, 1966; Dixon, 1967).

Useful information concerning metabolic requirements of the bacterial component in the symbiosis can be obtained through the use of auxotrophic mutants of Rhizobium which are 
defective at various stages of nodule formation (Schwinghamer, I969). Schwinghamer (I970) described a riboflavin-requiring auxotrophic mutant of Rhizobium trifolii, which formed ineffective or partially effective nodules on some cultivars of clover in the absence of riboflavin, but was fully effective when riboflavin was added externally to the roots of growing seedlings. Such biochemical restoration, as well as genetic restoration of effectiveness by back mutation to non-requirement for riboflavin, suggested that the block in nodule development involved a demand for riboflavin which is normally synthesized by the effective parent strain. The requirement for riboflavin appeared to be maximal approximately 6 to 8 days after inoculation, coincident with the beginning of bacteroid formation.

The present study was undertaken (i) to ascertain the differences in both structure and function (nitrogenase activity) of nodules produced by the riboflavin-requiring auxotroph on red clover seedlings grown with or without added riboflavin, and (ii) to determine more accurately the stage of nodule development at which riboflavin requirement is most critical.

\section{METHODS}

Cultures of Rhizobium. The effective parent strain TI and the ineffective riboflavinrequiring auxotroph TI/D-his ${ }^{r}-I_{5}$ (isolated from TI as a D-histidine resistant mutant, Schwinghamer, I969) were maintained on a glucose-salts-yeast extract agar medium.

Plant culture and inoculation. All host plant nodulation experiments were done with one cultivar of red clover (Trifolium pratense L.) cv. Kenland, as described below.

(i) Nodules for light and electron microscopy and for studying the effects of added riboflavin on nodulation by TI/D-his ${ }^{r}-15$ were produced on plants grown in sterile vermiculite in $8 \mathrm{oz}$ glass jars, as described previously (Schwinghamer, 1967, 1970). Seedlings were inoculated 8 days after planting at a concentration of about $10^{6} \mathrm{rhizobia} / \mathrm{ml}$ plant nutrient solution in the jars. They were maintained in a growth cabinet, under the following conditions: temperature $22^{\circ}$ ( $18 \mathrm{~h}$ light period) and $19^{\circ}(6 \mathrm{~h}$ dark period); light intensity was about I000 ft-candles, from a combination of warm white and daylight $40 \mathrm{~W}$ fluorescent tubes.

(ii) Plants used for studying the effects of addition and removal of riboflavin were grown in hydroponic culture under bacteriologically controlled conditions. Each glass jar was wrapped with aluminium foil, to exclude light from the roots. Four holes ( $\frac{1}{4}$ in diam.) drilled in the lids were covered with autoclavable tape and a 3 in hypodermic needle was inserted in the centre of the lid for aeration. Each jar assembly, containing nitrogen-free ' $S_{b}$ ' nutrient solution (Schwinghamer, 1960), was then autoclaved. Six-day-old seedlings germinated in vermiculite were aseptically transplanted by inserting the root through a slit cut into the tape covering each of the four holes in the lid. Seedlings were inoculated (about $10^{6}$ rhizobia $/ \mathrm{ml}$ ) 2 days later. The nutrient solution in each jar was gently aerated with filtered air, beginning 3 days after inoculation. Plants were grown under conditions similar to those of (i) in a glasshouse (temperature $22^{\circ}$ day, $16^{\circ}$ night). For the removal of riboflavin, the lids supporting the plants were removed from the jars and the plant roots immersed briefly in two changes of sterile water before transfer to a jar of fresh nutrient solution.

Stock solutions of riboflavin (I00 $\mu \mathrm{g} / \mathrm{ml}$ ) were sterilized by Millipore membrane $(0.45 \mu \mathrm{m}$ pore size) filtration and added to the jars to give an initial concentration of $8 \mu \mathrm{g} / \mathrm{ml}$.

\section{Microscopy}

Light microscopy. For examination of gross nodule structure, serial microtome sections (6 to $8 \mu \mathrm{m}$ ) were cut from paraffin-embedded material and stained with Heidenhain's 
haematoxylin and safranin. For detailed study of individual cells, sections $0.5 \mu \mathrm{m}$ thick were cut from embedded material prepared for electron microscopy and stained by the method of Huber, Parker \& Odland (I968).

Electron microscopy. For examination of fine structure, nodule tissue was fixed in $3 \%$ glutaraldehyde in $0.025 \mathrm{M}$-phosphate buffer, $\mathrm{pH} 7.0$, for $2 \mathrm{~h}$, washed in three changes of the same buffer for $\frac{1}{2} \mathrm{~h}$, and then treated with $2 \%$ osmium tetroxide in $0.025 \mathrm{M}$-phosphate buffer, $\mathrm{pH} 7 \cdot 0$, for $\mathrm{I} \frac{1}{2} \mathrm{~h}$. The tissues were then dehydrated in $25 \%, 50 \%, 75 \%, 95 \%$ ' and absolute ethanol and infiltrated with Epon through propylene oxide. Embedding was done under vacuum and the blocks were polymerized at $85^{\circ}$ for $24 \mathrm{~h}$. Thin sections were cut with glass knives, on a LKB 'Ultratome', stained with saturated uranyl acetate in $50 \%$ ethanol followed by lead citrate, and examined in a Phillips EM200 electron microscope at $80 \mathrm{kV}$.

Acetylene reduction by nodulated root systems. Nodulated roots from either two or three plants were placed in glass vials ( $13.5 \mathrm{ml}$ capacity) sealed with air-tight rubber stoppers. The vials were immediately evacuated, filled to I atm with a gas mixture comprising $20 \%$ $\mathrm{O}_{2}, 20 \% \mathrm{C}_{2} \mathrm{H}_{2}$ and $60 \%$ argon, and placed in an incubator at $22^{\circ}$. After $30 \mathrm{~min}, 200 \mu \mathrm{l}$ gas was withdrawn and the ethylene concentration determined as described by Bergersen (I970).

Total nitrogen. Plant shoots were oven-dried at $70^{\circ}$ for $48 \mathrm{~h}$, then subjected to Kjeldahl digestion. Total nitrogen was determined by the colorimetric method of Williams \& Twine (I967).

\section{RESULTS}

\section{Examination of nodule structure by light microscopy}

Nodules formed by the parent strain TI were structurally similar to those formed by other effective strains of Rhizobium trifolii on clover species (e.g. Bergersen, 1955). Longitudinal sections of 3-day-old nodules* (Fig. I $a$ ) showed that apical meristem, central bacteroid zone, external cortical region and vascular traces were already well developed. Further growth increased the volume of the bacteroid zone.

Examination of sections of 2- to 3-day-old nodules formed by TI/D-his ${ }^{\mathrm{r}}$-I 5 showed that very few of the invaded cells in the central region of the nodule contained morphologically distinct bacteroids. The majority of rhizobia released into these cells had not developed and remained as vegetative rods in the peripheral cytoplasm. Fig. I $b$ shows the general features of such a nodule, the central cells appearing rather empty and significantly $(P<0.01)$ reduced in size (an average diameter of $36 \mu \mathrm{m}$ compared to an average diameter of $40 \mu \mathrm{m}$ in TI nodules of the same age). Sections from older nodules, however, indicated that an increasing number of cells in the basal regions of the central zone did become enlarged and filled with bacteria (Fig. I $c$ ). Most of the bacteria in these cells had developed into bacteroids but a few vegetative rods still remained (Fig. I $d$ ). The bacteroids were less swollen and less regular in shape than those in similar regions of nodules formed by TI (Fig. I $e$ ), and many amyloplasts were present around the periphery of the cells.

Previous work (Schwinghamer,' I970), based on plant dry weight and nitrogen content data, showed that the effect of riboflavin upon nodules formed by $\mathrm{TI} / \mathrm{D}$-his ${ }^{\mathrm{r}}$ - 5 was greatest when the vitamin was added soon after inoculation, and was much less when the addition was delayed. This was confirmed in the present work. Nodules formed on plants which received riboflavin at the time of inoculation with $T r / D-h^{2}{ }^{r}-I 5$ or at 3 days after inoculation were structurally identical with the effective nodules produced by TI. When the riboflavin

\footnotetext{
* In referring to nodule age, day $o$ is taken as the day of appearance of the nodule, i.e. 5 to 6 days after inoculation.
} 

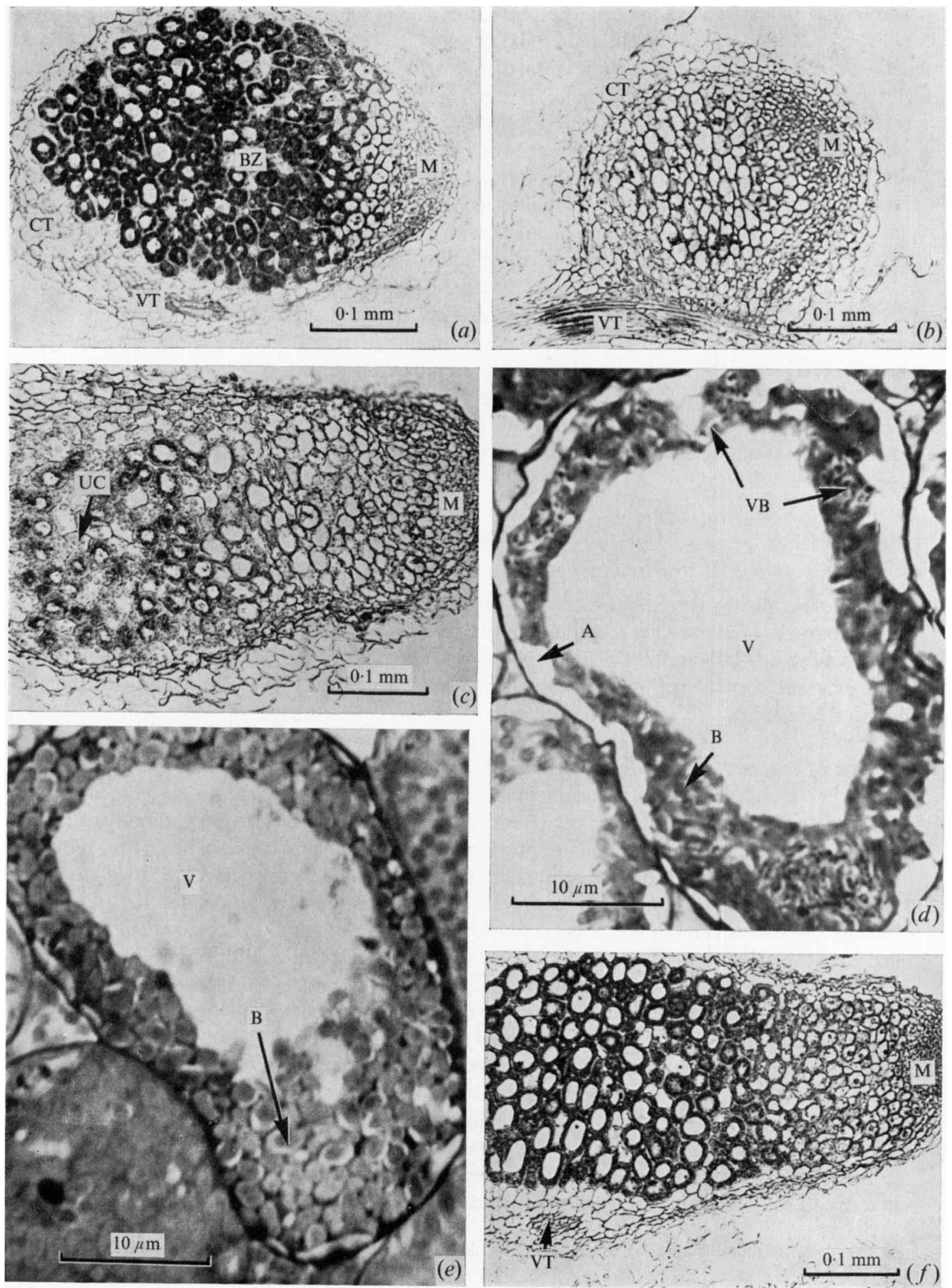


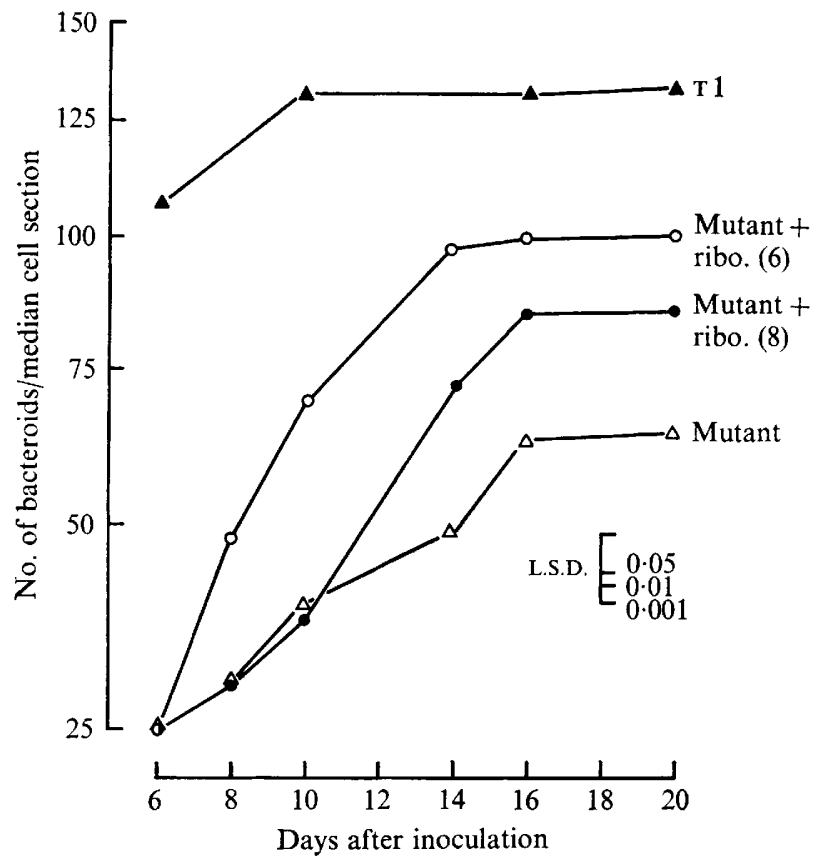

Fig. 2. The effect of riboflavin on the total number of bacteroids per cell section (6 to $8 \mu \mathrm{m}$ thick) in nodules formed by $\mathrm{TI} / \mathrm{D}-\mathrm{his}^{\mathrm{r}}$-I 5 on Kenland red clover. Numbers in parenthesis indicate the number of days between inoculation and riboflavin addition. Each point is the mean value of counts made from 20 individual cells. Least significant differences (L.S.D.) were obtained by square root transformation of individual counts.

was added 6 or 8 days after inoculation with TI/D-his ${ }^{\mathrm{r}}$ - 5 and the nodules examined 2, 4 and 8 days later, there was an increase, relative to nodules from plants receiving no riboflavin, in the numbers of bacteroids in the cells of the central zone, and all nodule cells infected thereafter developed normally. Figure $I(f)$ shows a section of a nodule 8 days after riboflavin addition at day 6.

To confirm this apparent effect of riboflavin on total numbers of bacteroids per host cell, counts were made from cells in the middle of the central zone from median nodule sections. Five or six nodules were examined at various intervals after inoculation and riboflavin

Fig. I. Light micrographs. $\mathrm{A}=$ amyloplast, $\mathbf{B}=$ bacteroid, $\mathrm{BZ}=$ region of mature bacteroids, $\mathrm{CT}=$ cortex, $\mathrm{M}=$ meristem, $\mathrm{UC}=$ uninfected cell, $\mathrm{V}=$ vacuole, $\mathrm{VB}=$ vegetative bacterium, $\mathrm{VT}=$ vascular trace.

(a) A longitudinal section of a 3-day-old nodule formed by TI, showing the meristem, central zone containing mature bacteroids, external cortex and vascular traces.

(b) A longitudinal section of a 3-day-old nodule formed by TI/D-his ${ }^{r}-15$. Note the small size of the central zone cells which do not appear to contain bacteria.

(c) A longitudinal section of an 8-day-old nodule formed by TI/D-his ${ }^{T}-15$. The cells in the basal region of the central zone now contain many bacteria.

(d) A longitudinal section of a mature cell in the basal region of the central zone of a 12-day-old nodule formed by TI/D-his ${ }^{r}-15$. Numerous amyloplasts are present around the periphery of the cell, which is seen to contain relatively unswollen bacteroids and vegetative bacteria.

(e) A longitudinal section of a mature bacteroid-containing cell in a 12-day-old nodule formed by T1. Note the absence of amyloplasts and undeveloped vegetative bacteria.

(f) A longitudinal section of a nodule formed by TI/D-his ${ }^{r}-158$ days after riboflavin addition at day 6 (i.e. 6 days after inoculation). Note the well-developed bacteroid-containing cells at the base of the nodule and the large region of newly invaded cells distal to the meristem. 


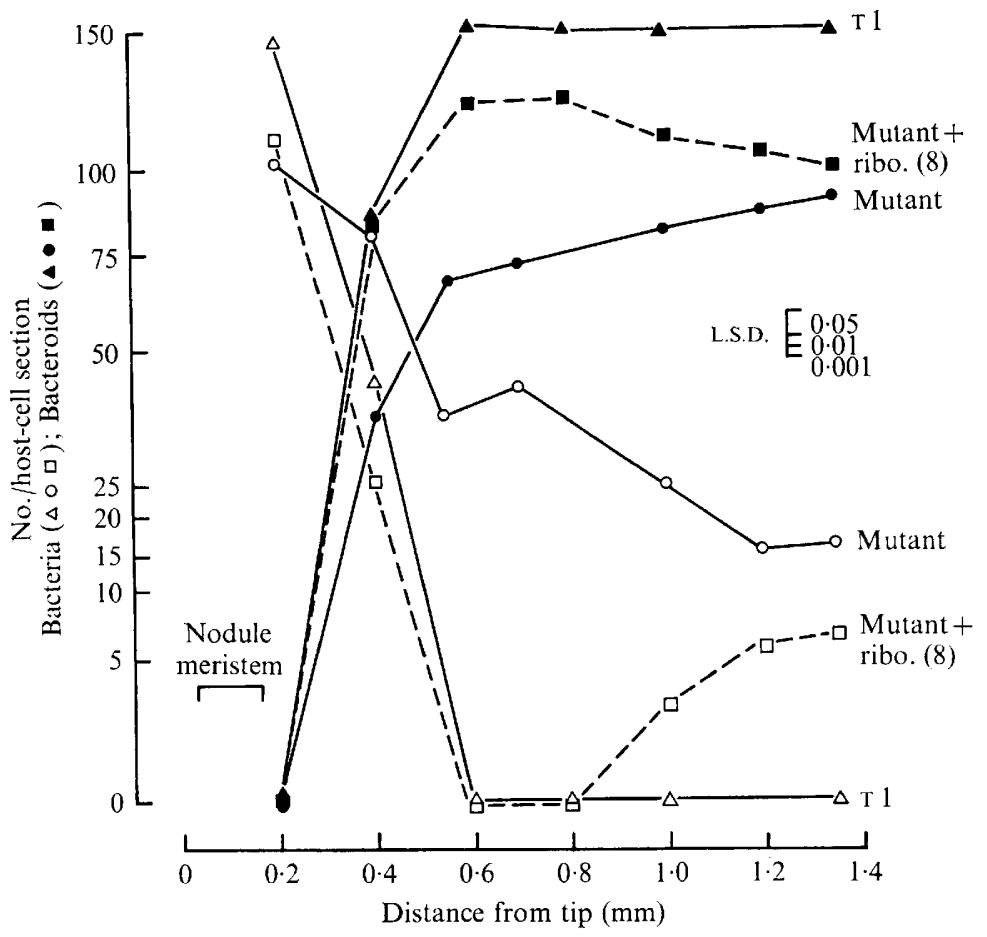

Fig. 3. Comparison of bacteroid and vegetative bacteria counts in cells of the central zone of I4-day-old nodules formed by TI, TI/D-his ${ }^{r}-I_{5}$, and TI/D-his ${ }^{r}-5_{5}+$ riboflavin (added 8 days after inoculation) on Kenland red clover. Counts were made from cell sections $0.5 \mu \mathrm{m}$ thick. Each point is the mean value of counts made from 15 individual cells. The shaded symbols designate bacteroids, the unshaded symbols vegetative bacteria. Least significant differences were obtained by square root transformation of individual counts.

addition, and only those cells cut in a median plane were considered. It was found that the bacteroid number per cell section ( 6 to $8 \mu \mathrm{m}$ thick) in nodules receiving riboflavin 6 or 8 days after inoculation increased significantly but did not reach the TI level (Fig. 2). This suggested three possibilities: (i) that fewer rhizobia had been released into the host cells initially; (ii) that those released underwent little or no multiplication; (iii) that many of those released were unable to respond to the added riboflavin by becoming bacteroids. Bacteroid and vegetative rod counts made from serial sections $(0.5 \mu \mathrm{m}$ thick beginning at the apical meristem and progressing back through the nodule) of individual I4-day-old nodules are given in Fig. 3 . In the case of the TI/D-his ${ }^{r}-15$ nodule examined, cells in the centre of the nodule contained approximately $60 \%$ bacteroids and $40 \%$ vegetative rods, with the proportion of bacteroids increasing gradually to almost $85 \%$ in the basal cells. With the addition of riboflavin, cells near the meristem were almost normal, with complete conversion of vegetative rods into bacteroids, but towards the base of the nodule the cells still contained many rods. It is also apparent from Fig. 3 that fewer rods were present in the host cells immediately after their release from infection threads in the nodule produced by TI/D-his ${ }^{\mathrm{r}}-\mathrm{I} 5$, even in the presence of riboflavin, than in the case of the TI nodule. This suggests that multiplication and/or release of the mutant vegetative cells from the infection thread was impaired. 


\section{Electron microscopy}

Electron microscopy confirmed the observations made with the light microscope, namely that additional riboflavin was required by $\mathrm{TI} / \mathrm{D}-\mathrm{his}^{\mathrm{r}} \mathrm{-} 5 \mathrm{5}$ for the conversion of vegetative rods into bacteroids. The pattern of development of typical infected cells in TI/D-his ${ }^{\mathrm{r}}-\mathrm{I} 5$ and TI nodules is illustrated in Fig. 4. Bacteroid formation is completed in host cells which are still close to the meristem in a normal effective TI module, the released rhizobia assuming a homogeneous appearance (Fig. $4 a$ ), before undergoing enlargement (Fig. $4 b$ ). In contrast, the rhizobia released into host cells in the TI/D-his ${ }^{r}-\mathrm{I} 5$ nodule remain in the vegetative state for some time (Fig. 4 c); eventually a few develop into bacteroids. A section of a mature cell in a TI/D-his ${ }^{r}-$ I5 nodule is shown in Fig. $4(d)$. It can be seen that a number of bacteroids have developed and reached their normal size (see Fig. $4 b$ ), while others are still not fully enlarged. Many vegetative rods remain enclosed by their host envelopes (Fig. $4 d, 5 a$ ). Some have divided and others show signs of degeneration (irregular cell outline and apparent breakdown of contents) (Fig. 5 a).

An abnormality possibly related to the impaired release of rhizobia from the infection thread (see Fig. 3) was observed in some newly infected cells of I2-day-old Tr/D-his ${ }^{r}-15$ nodules. Normally a compact matrix of material which is probably polysaccharide surrounds the rhizobia within the infection thread and also when they are being released from the thread (Dart \& Mercer, 1963; Fig. 5b). In older nodules produced by the mutant, this material was greatly increased in amount and often occupied up to $50 \%$ of the area of cell sections (Fig. $5 c$ ).

Host cells in the apical regions of TI/D-hisr-I5 nodules examined 8 days after the addition of riboflavin (at day 6 or day 8) were structurally similar to cells in corresponding regions of TI nodules. It was also evident that many of the vegetative rods and immature bacteroids in the basal cells of the TI/D-his $\mathrm{r}_{-} \mathrm{I} 5$ nodules had developed fully. Those which had failed to do so had degenerated within their enclosing host envelopes (Fig. $5 d$ ). The number of mitochondria in these cells appeared to have increased and many were clustered near amyloplasts (Fig. $5 d$ ).

\section{The effect of addition and removal of riboflavin}

The effect on $\mathrm{N}_{2}$-fixation of (i) the addition or (ii) the subsequent removal of riboflavin from plants inoculated with TI/D-his ${ }^{\mathrm{r}}-\mathrm{I} 5$ was followed by measuring the acetylene $\left(\mathrm{C}_{2} \mathrm{H}_{2}\right)$ reducing activity of nodulated plants at intervals during their growth.

Addition of riboflavin. In these experiments, riboflavin was added at an initial concentration of $8 \mu \mathrm{g} / \mathrm{ml}$, at day zero (i.e. with the inoculum), at day 3, or at day 6 after inoculation. $\mathrm{C}_{2} \mathrm{H}_{2}$-reducing activity was measured $7,8,9,10, \mathrm{I} 2$, and $\mathrm{I} 4$ days after inoculation, on complete roots bearing nodules, harvested in the middle of the daylight part of the photoperiod. Nodule counts were made on all plants and each nodule was classified as either pigmented (distinct pink coloration) or non-pigmented. Results are shown in Fig. 6 and in Table I. The following observations are derived from the data: (i) plants inoculated with TI/D-his ${ }^{\mathrm{r}-\mathrm{I}} 5$ without riboflavin reduced $\mathrm{C}_{2} \mathrm{H}_{2}$ at a low level (about I5\% of TI at day I4); (ii) addition of riboflavin with the inoculum allowed TI/D-his ${ }^{r}-15$ nodules to develop and fix $\mathrm{N}_{2}$ at a rate similar to that of TI nodules; (iii) delayed addition of riboflavin caused a lag in the attainment of a given level of fixation; the lag increased with increase in the delay. The nodules recovered and resumed growth when the riboflavin was withheld for as long as 6 days after inoculation; (iv) plants inoculated with TI/D-hisr-15 without riboflavin formed approximately one-half the number of nodules produced by TI; (v) addition of riboflavin at day 3 

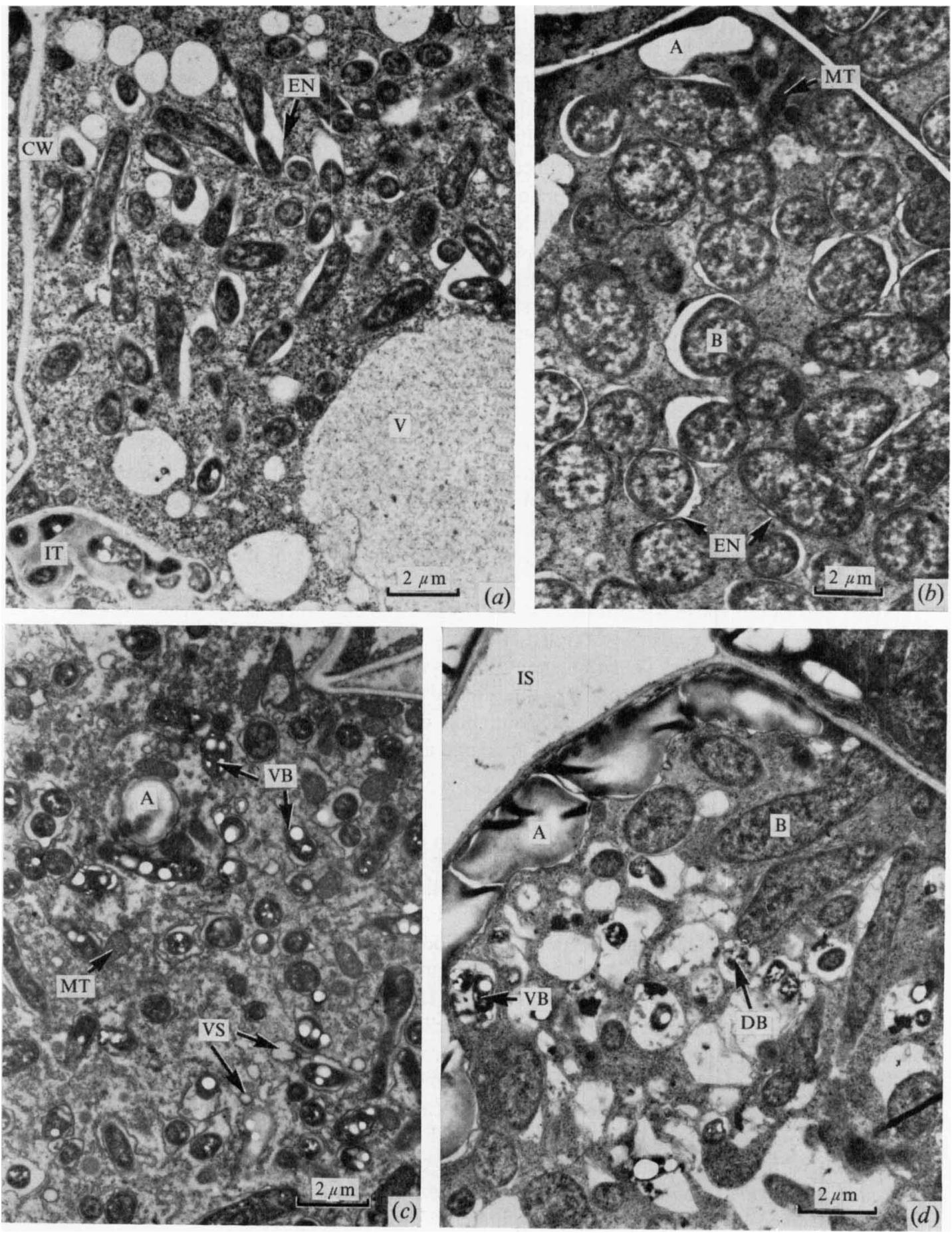
resulted in the normal (cf. Tr) number of nodules being present at day 7 on plants inoculated with TI/D-his ${ }^{\mathrm{r}}$-I 5 ; addition at day 6 resulted in a normal complement by day IO. Under the conditions of these experiments, nodules produced by TI generally appeared at about 6 days after inoculation. The 4 days required for approximately half of the TI/D-his ${ }^{\mathrm{r}}$ I 5 nodules to appear after late addition of riboflavin suggests that either many root-hair infections by the auxotrophic rhizobia were arrested but resumed development when the riboflavin was supplied, or that new infections occurred which were able to develop faster than normal; (vi) the increase in percentage of pigmented nodules after riboflavin addition paralleled the increase in $\mathrm{C}_{2} \mathrm{H}_{2}$ reduction.

Removal of riboflavin. In these experiments riboflavin was added to the plants at days $\mathrm{o}$, 3,4 or 6 (after inoculation with TI/D-his ${ }^{r}-I_{5}$ ) and then removed at various times, to ascertain whether the need for added riboflavin applies only to the young developing nodule or persists throughout the active life of the nodule. Plants were allowed to grow for 18 days after inoculation, then were harvested for dry weight and total nitrogen determinations. These results are shown in Table 2. It was found that addition of riboflavin at day o and its removal at day 3 resulted in only an insignificant gain in dry weight and total nitrogen relative to TI/D-his ${ }^{\mathrm{r}}-\mathrm{I} 5$ alone. Removal at days 4 and 5 gave a significant gain (partially effective plant response), while removal at days 6,7 and 8 resulted in an almost fully effective response. Similarly, when riboflavin was added on days 3, 4 or 6 after inoculation, exposure of the plants to the vitamin for 3 or 4 days allowed a partial growth response; exposure for about 6 days gave a response similar to that obtained with the continual presence of riboflavin. The maximum stimulation effect was obtained when riboflavin was added at day o or day 3, and removed at day 6 to 7 or day 7 to 8 respectively. The results suggest that the need for an external vitamin supply was minimal during the first 3 days after inoculation, rose sharply to a maximum at about 7 to 9 days (when pigmentation and bacteroid formation had commenced), and then diminished. It is not known from these short-term experiments however, whether the need for riboflavin per se is reduced after this stage of growth, or whether a continuing need is in fact satisfied by the riboflavin accumulated by the plant.

The effect of removal of external riboflavin was also measured by $\mathrm{C}_{2} \mathrm{H}_{2}$-reducing activity, which allows a more precise determination of the time when changes in nodule function occur. In these experiments riboflavin was added at day o (with the TI/D-his ${ }^{\mathrm{r}}-\mathrm{I} 5$ inoculum), and removed at days 3,5 and 7 (Fig. 7). Removal of riboflavin at day 3 allowed a small increase in $\mathrm{C}_{2} \mathrm{H}_{2}$-reducing activity. Removal at day 5 resulted in an intermediate rate and removal at day 7 allowed an increasing rate, similar to the control in which riboflavin was not removed. These results are consistent with the plant nitrogen data obtained in other experiments (Table 2).

Fig. 4. Electron micrographs. $\mathrm{A}=$ amyloplast, $\mathrm{B}=$ bacteroid, $\mathrm{CW}=$ cell wall, $\mathrm{DB}=$ degenerating bacterium, EN = enclosing membrane envelope, IS = intercellular space, IT = infection thread, $\mathrm{MT}=$ mitochondria, $\mathbf{P B}=$ granules assumed to be poly- $\beta$-hydroxybutyrate, $\mathrm{V}=$ vacuole, $\mathrm{VB}=$ vegetative bacterium.

(a) A section of a newly invaded cell in a I2-day-old nodule formed by $\mathrm{TI}$. The bacteria released from the infection thread are enclosed within envelopes and have begun to enlarge. The bacteria have no granules of low electron scattering properties.

(b) A section of a mature bacteroid-containing cell in a TI nodule, showing swollen bacteroids.

(c) A portion of an invaded cell in a I2-day-old nodule formed by TI/D-his ${ }^{\mathrm{r}}-\mathrm{I} 5$. The released bacteria have prominent, non-electron scattering granules assumed to be reserves of poly- $\beta$ hydroxybutyrate, and show no signs of enlargement.

(d) A section of a mature cell in the central zone of a 12-day-old nodule formed by TI/D-his ${ }^{\mathrm{r}}-\mathrm{I} 5$, showing fully developed bacteroids, vegetative bacteria, and vegetative bacteria undergoing degeneration. 

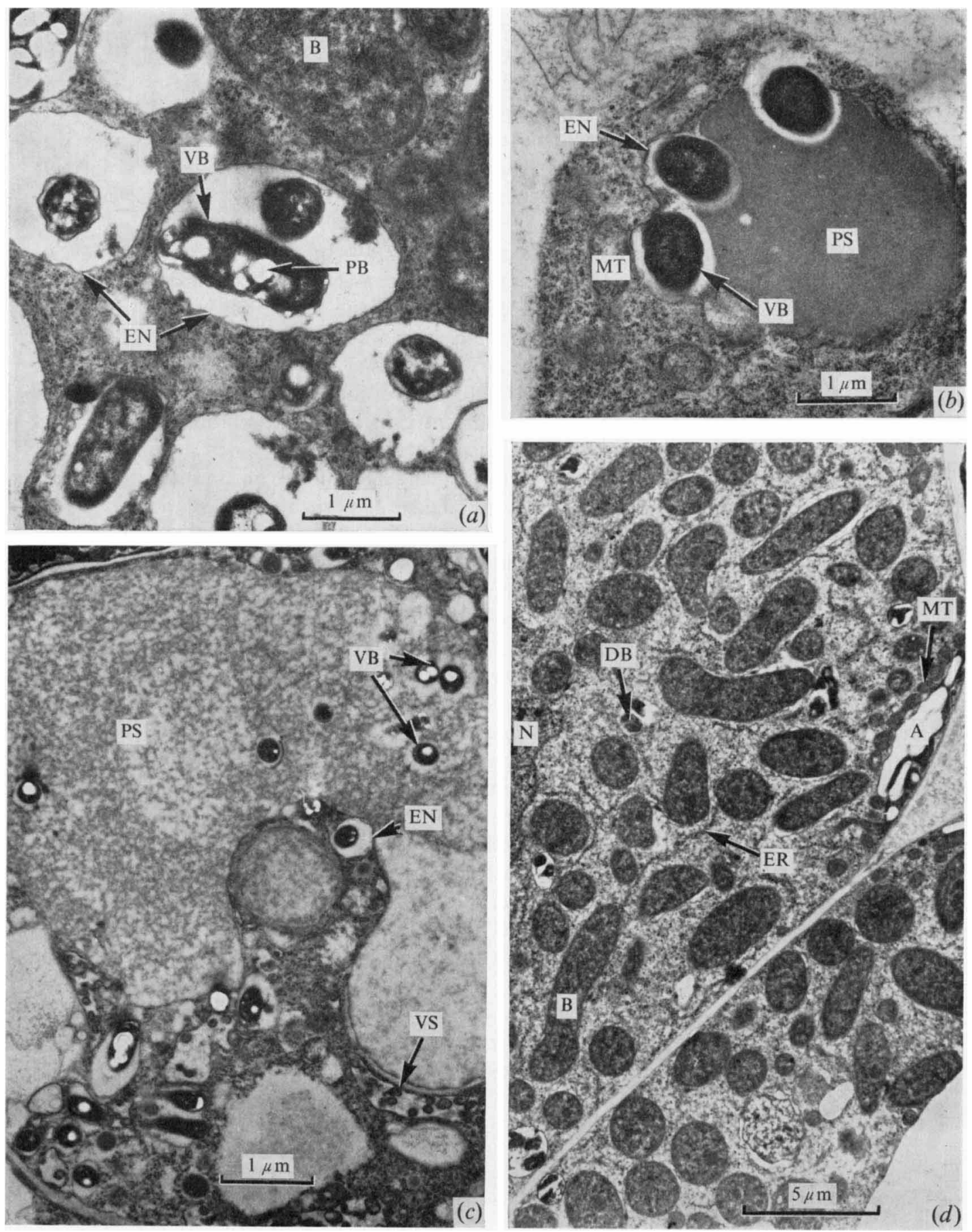


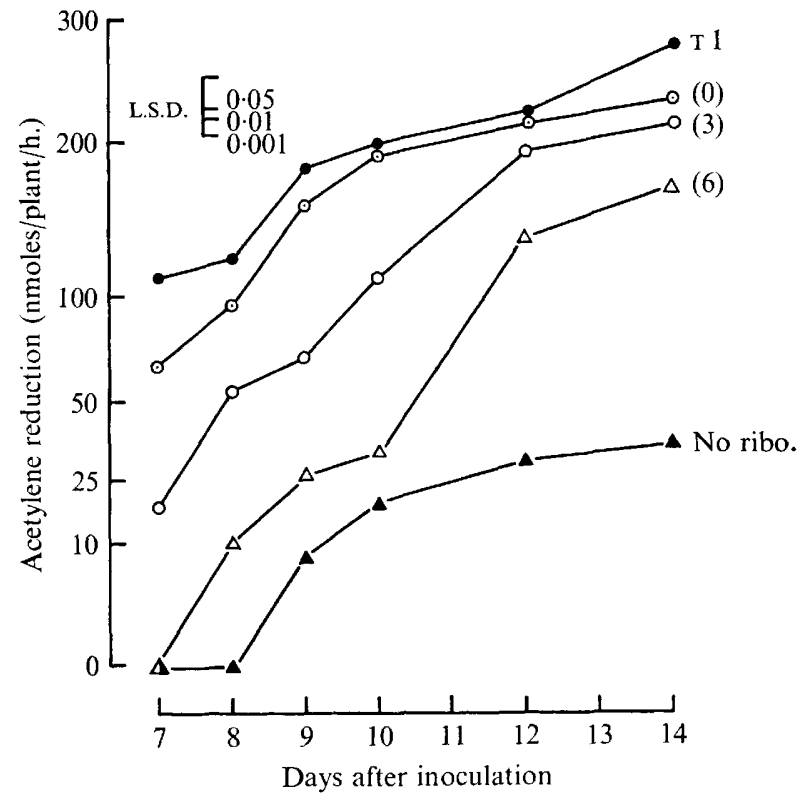

Fig. 6. The effect of the addition of riboflavin on the $\mathrm{C}_{2} \mathrm{H}_{2}$-reducing activity of plants inoculated with TI/D-his ${ }^{r}$-I 5 . Numbers in parentheses indicate the number of days between inoculation and riboflavin addition. Each point is the mean of four assays, three nodulated root systems per assay. Least significant differences were obtained by square-root transformation of values for individual assays.

Data on the number of root nodules formed per plant in these experiments (Table 3), again show that the unsupplemented auxotroph formed only half as many nodules as the plus-riboflavin control. When riboflavin was present for 3 days or longer the number of nodules appearing by day 7 was similar to that of the plus-riboflavin control (cf. addition at day 3 , Table I).

\section{Miscellaneous experiments}

Several limited attempts were made to overcome the apparent inability of the host plant to supply sufficient riboflavin during the presumed critical period ( 7 to 9 days after inocula-

Fig. 5. Electron micrographs. $\mathrm{A}=$ amyloplast, $\mathrm{B}=$ bacteroid, $\mathrm{DB}=$ degenerating bacterium, $\mathrm{EN}=$ enclosing membrane envelope, $\mathrm{ER}=$ endoplasmic reticulum, $\mathrm{MT}=$ mitochondria, $\mathrm{N}=$ host cell nucleus, $\mathbf{P B}=$ granules assumed to be poly- $\beta$-hydroxybutyrate, $\mathbf{P S}=$ polysaccharide, $\mathrm{VB}=$ vegetative bacterium, VS = small vesicles.

(a) An electron micrograph showing vegetative bacteria enclosed by their host envelopes adjacent to a mature bacteroid in a mature cell of a TI/D-his ${ }^{\mathrm{r}}-\mathrm{I} 5$ nodule.

(b) A transverse section of a 4-day-old nodule formed by TI/D-his ${ }^{r}-15$, at the stage of bacterial release. The bacteria are embedded in a matrix of material assumed to be polysaccharide which has been extruded from the infection thread. The matrix is surrounded by a membrane, known to be continuous with the host cell membrane surrounding the infection thread, and the bacteria are in process of entering the cytoplasm by endocytosis (cf. Goodchild \& Bergersen, 1966).

(c) A section of an infection thread in a I2-day-old nodule formed by TI/D-his ${ }^{r}-15$. Note the large quantity of matrix material surrounding the bacteria as they are being released. Aggregates of small vesicles enclosed by a membrane can also be seen in the cytoplasm of the cell.

(d) A section of a mature cell in a nodule formed by TI/D-his ${ }^{r}-15$ IO days after riboflavin addition at day 6 (i.e. 6 days after inoculation). Those rhizobia unable to respond to the added riboflavin have degenerated within their host envelopes. Mitochondria are conspicuous and clustered near amyloplasts. Profiles of the endoplasmic reticulum are also prominent in the cytoplasm of the cell. 


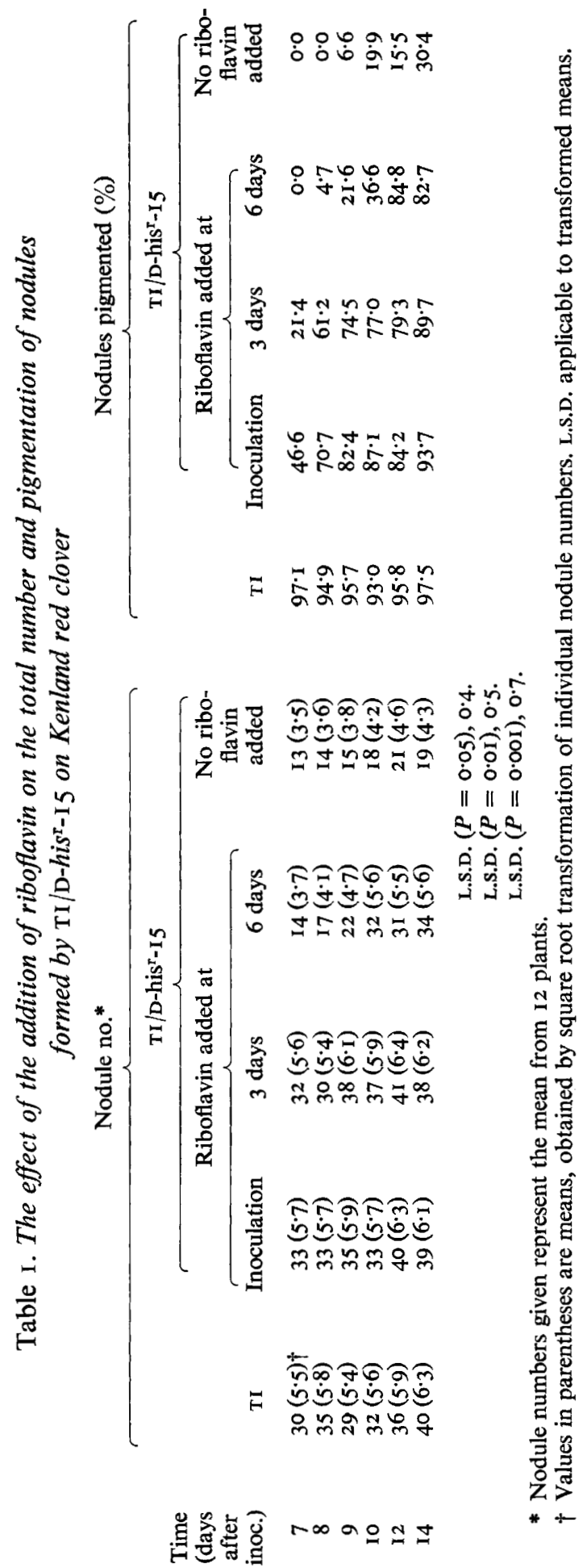


Table 2. The effect of the addition and subsequent removal of riboflavin on the dry weight and total nitrogen content of shoots of Kenland red clover, 18 days after inoculation with $\mathrm{TI} / \mathrm{D}-$ his $^{\mathrm{r}}-\mathrm{I} 5$

\begin{tabular}{|c|c|c|c|c|c|c|}
\hline & \multicolumn{2}{|c|}{ Riboflavin } & \multirow{2}{*}{\multicolumn{2}{|c|}{$\underset{\text { (mg) }}{\text { Mean dry wt }}$}} & \multirow{2}{*}{\multicolumn{2}{|c|}{$\underset{(\mathrm{mg})}{\operatorname{Mean} N}$}} \\
\hline & Day & Day & & & & \\
\hline \multicolumn{7}{|c|}{ Experiment I } \\
\hline $\begin{array}{l}\text { Non-inoculated } \\
\text { Non-inoculated + ribo. } \\
\text { Tr/D-his }-15\end{array}$ & & & $\begin{array}{l}54 \\
59 \\
79\end{array}$ & $\begin{array}{l}(\mathrm{I} \cdot 73)^{*} \\
(\mathrm{I} \cdot 77) \\
(\mathrm{I} \cdot 90)\end{array}$ & $\begin{array}{l}0.91 \\
0.99 \\
I \cdot 27\end{array}$ & $\begin{array}{l}(0 \cdot 95) \dagger \\
(0 \cdot 99) \\
(1 \cdot 12)\end{array}$ \\
\hline TI/D-his ${ }^{r}-\mathrm{I} 5$ + ribo. & $\begin{array}{l}0 \\
0 \\
0 \\
0 \\
0 \\
0\end{array}$ & $\begin{array}{c}3 \\
4 \\
5 \\
6 \\
7 \\
-8\end{array}$ & $\begin{array}{r}83 \\
120 \\
119 \\
161 \\
195 \\
173 \\
213\end{array}$ & $\begin{array}{l}(1 \cdot 92) \\
(2 \cdot 08) \\
(2 \cdot 07) \\
(2 \cdot 20) \\
(2 \cdot 29) \\
(2 \cdot 23) \\
(2 \cdot 32)\end{array}$ & $\begin{array}{l}I \cdot 62 \\
2 \cdot 08 \\
2 \cdot 09 \\
3 \cdot 22 \\
3 \cdot 78 \\
4 \cdot 21 \\
5 \cdot 89\end{array}$ & $\begin{array}{l}(\mathrm{I} \cdot 27) \\
(\mathrm{I} \cdot 44) \\
(\mathrm{I} \cdot 44) \\
(\mathrm{I} \cdot 79) \\
(\mathrm{I} \cdot 94) \\
(2 \cdot 05) \\
(2 \cdot 42)\end{array}$ \\
\hline \multicolumn{7}{|c|}{ Experiment 2} \\
\hline $\begin{array}{l}\text { Non-inoculated } \\
\text { TI/D-his }{ }^{r}-15\end{array}$ & & & $\begin{array}{l}42 \\
59\end{array}$ & $\begin{array}{l}(1 \cdot 62)^{*} \\
(1 \cdot 76)\end{array}$ & $\begin{array}{l}0.82 \\
1 \cdot 02\end{array}$ & $\begin{array}{l}(0.89) \dagger \\
(1 \cdot 01)\end{array}$ \\
\hline TI/D-his'-I5 + ribo. & $\begin{array}{l}3 \\
3 \\
3 \\
3 \\
3 \\
3\end{array}$ & $\begin{array}{c}5 \\
6 \\
7 \\
8 \\
9 \\
-8\end{array}$ & $\begin{array}{r}76 \\
73 \\
145 \\
146 \\
\text { I } 55 \\
\text { I } 53\end{array}$ & $\begin{array}{l}(1 \cdot 87) \\
(1 \cdot 86) \\
(2 \cdot 16) \\
(2 \cdot 16) \\
(2 \cdot 18) \\
(2 \cdot 18)\end{array}$ & $\begin{array}{l}1.41 \\
1.27 \\
2.57 \\
2.65 \\
3.42 \\
4.22\end{array}$ & $\begin{array}{l}(\mathrm{I} \cdot \mathrm{I} 8) \\
(\mathrm{I} \cdot \mathrm{I}) \\
(\mathrm{I} \cdot 60) \\
(\mathrm{I} \cdot 62) \\
(\mathrm{I} \cdot 85) \\
(2 \cdot 05)\end{array}$ \\
\hline TI/D-his ${ }^{r}-15$ +ribo. & $\begin{array}{l}4 \\
4 \\
4 \\
4 \\
4\end{array}$ & $\begin{array}{c}6 \\
7 \\
8 \\
9 \\
-8\end{array}$ & $\begin{array}{r}83 \\
88 \\
128 \\
162 \\
161\end{array}$ & $\begin{array}{l}(1 \cdot 92) \\
(1 \cdot 94) \\
(2 \cdot 08) \\
(2 \cdot 21) \\
(2 \cdot 20)\end{array}$ & $\begin{array}{l}1 \cdot 70 \\
1 \cdot 76 \\
2 \cdot 10 \\
2 \cdot 72 \\
3 \cdot 90\end{array}$ & $\begin{array}{l}(\mathrm{I} \cdot 30) \\
(\mathrm{I} \cdot 32) \\
(\mathrm{I} \cdot 45) \\
(\mathrm{I} \cdot 65) \\
(\mathrm{I} \cdot 97)\end{array}$ \\
\hline TI/D-his'-15 + ribo. & $\begin{array}{l}6 \\
6 \\
6\end{array}$ & $\begin{array}{c}9 \\
12 \\
-\S\end{array}$ & $\begin{array}{r}58 \\
116 \\
135\end{array}$ & $\begin{array}{l}(1 \cdot 76) \\
(2 \cdot 06) \\
(2 \cdot 13)\end{array}$ & $\begin{array}{l}1 \cdot 00 \\
1 \cdot 89 \\
3 \cdot 27\end{array}$ & $\begin{array}{l}(\mathrm{I} \cdot 00) \\
(\mathrm{I} \cdot 37) \\
(\mathrm{I} \cdot 80)\end{array}$ \\
\hline TI (parent) & & & 208 & $(2 \cdot 31)$ & $6 \cdot 18$ & $(2 \cdot 48)$ \\
\hline $\begin{array}{l}\text { L.S.D. }(P=0.05) \\
\text { L.S.D. }(P=0.01) \\
\text { L.S.D. }(P=0.001)\end{array}$ & & & & $\begin{array}{l}(0.05) \\
(0.07) \\
(0.09)\end{array}$ & & $\begin{array}{l}(0.16) \\
(0.22) \\
(0.28)\end{array}$ \\
\hline
\end{tabular}

Mean values given are the average of three replicates (jars), four plants/replicate.

* Values in parentheses are logarithmically transformed values.

$\dagger$ Values in parentheses are square-root transformed values.

$\ddagger$ Days after inoculation. \& Riboflavin treatment continuous.

tion). Addition of $\left(\mathrm{NH}_{4}\right)_{2} \mathrm{SO}_{4}$ at a level of $2 \mu \mathrm{g} / \mathrm{ml}$ of $\mathrm{N}$ (equivalent to the nitrogen contained in the riboflavin normally added) at the time of inoculation or 4 days later had no effect on the ineffectiveness of TI/D-his ${ }^{\mathrm{T}-15}$. Similarly, decreasing the light intensity to about $500 \mathrm{ft}$ candles or increasing it to about $2000 \mathrm{ft}$-candles had no effect. Earlier inoculation (I day after germination, to allow infection before the riboflavin resources of the seeds were exhausted) or later inoculation (I9 days after germination) also were without effect. 


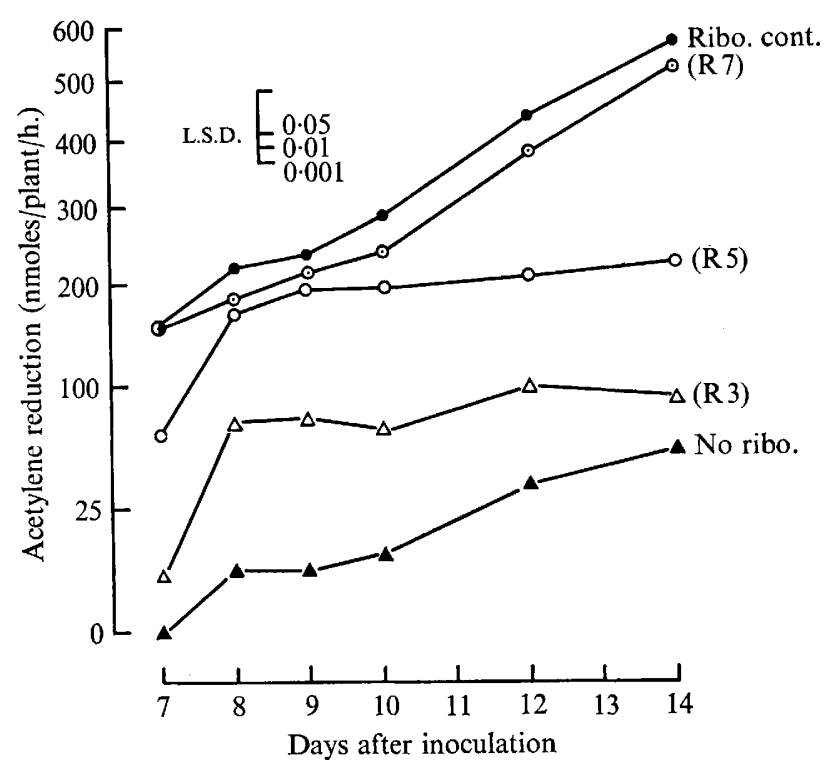

Fig. 7. The effect of the addition and subsequent removal of riboflavin on the $\mathrm{C}_{2} \mathrm{H}_{2}$-reducing activity of Kenland red clover plants inoculated with TI/D-his ${ }^{r}-15$. Riboflavin was added with the inoculum; the figures in parenthesis show the number of days between riboflavin addition and removal, e.g. $\mathrm{R}_{3}=$ removed at day three. Each point is the mean of 4 assays, 2 root systems per assay. Least significant differences were obtained by square-root transformation of values for individual assays.

\section{DISCUSSION}

In the symbiotic system examined in this investigation it has been shown that riboflavin, required for growth in vitro by a mutant of Rhizobium trifolii (TI/D-his ${ }^{r_{-}}$- 5), is also required by this strain for the conversion of vegetative cells into functional $\mathrm{N}_{2}$-fixing bacteroids within root nodules on Trifolium pratense. When riboflavin is not added to the plants, the mutant is able to form a reduced number of root nodules, but these are largely ineffective in $N_{2}$-fixation because a large proportion of the rhizobia released into the host cells do not develop into $\mathrm{N}_{2}$ fixing bacteroids. However, if riboflavin is added to the plant growth medium at inoculation, or up to 6 days later, most of these rhizobia develop normally into bacteroids and $\mathrm{N}_{2}$-fixation follows. This was shown by the fact that the nodules on treated plants reduced acetylene at a rate similar to that of nodules formed by the effective parent strain TI. The demand for riboflavin shown by the mutant thus appears to be greater for bacteroid formation than for vegetative growth. Whether riboflavin is required for increased electron transport in bacteroids (Wong, Evans, Klucas \& Russell, 1972) or whether it has some specific role in bacteroid formation is unknown. FMN was similar to riboflavin in restoring effectiveness to nodules by TI/D-his ${ }^{r}-\mathrm{I} 5$ (Schwinghamer, 1970), but FAD was less efficient, possibly due to lower uptake.

The period of riboflavin requirement during the initial stages of nodule development is short, and if the mutant is sustained through this period (i.e. until' 2 to 4 days after nodules have appeared) with added riboflavin, the nodules can then proceed to develop unaided. This could mean (i) that riboflavin is no longer required in large quantities after this phase of development has been completed, (ii) that the plant has accumulated adequate reserves from the external source, or (iii) that the plant has begun to synthesize a sufficient quantity. The evidence for (i) suggesting that the demand for riboflavin declines once the bacteroids reach a certain age is unlikely because new bacteroids are continually being formed in newly 


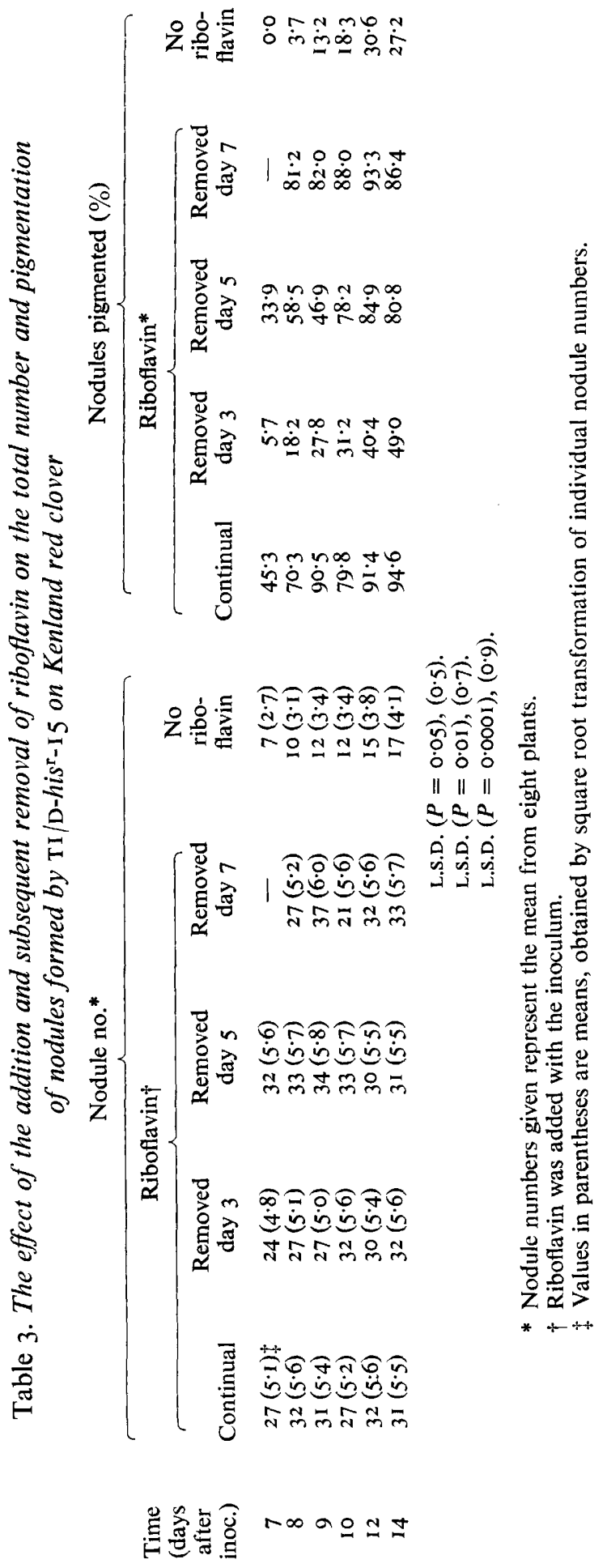


invaded cells in the nodules. Tuzimura (1950) has shown that soybean root nodules produced by an effective strain of Rhizobium japonicum contain large quantities of riboflavin (compared with the rest of the root), although the relative amounts produced by the bacteria and by the host cells were not fully ascertained. If this unequal accumulation is a function of the host plant, then the second possibility is quite likely. The Kenland cultivar of red clover could then be said to require at least 4 days of exposure to an external source of riboflavin to enable it to concentrate a sufficient amount to allow normal nodule development by TI/D-his ${ }^{\mathrm{r}}-\mathrm{I} 5$. The third possibility - that the plant synthesizes more riboflavin when it is 12 to 14 days old - is not supported by the negative response obtained when inoculation was delayed until this time. The possibility is not eliminated, however, because the negative result could have been influenced by the $\mathrm{N}$-deficiency experienced by plants of this age.

The impairment noted in the release of rhizobia from infection threads in newly invaded cells of older nodules ( 2 to 14 days after appearance) formed by the auxotroph alone is possibly another feature of nodules deficient in riboflavin. If this is the case, this observation is reminiscent of the 'starvation' effects observed by Brenchley \& Thornton (1925) in nodules formed on Vicia faba plants grown on a boron-deficient substrate, and of the induced parasitism of rhizobia in nodules formed on lucerne and clover plants grown in the dark (Thornton, 1930). In both cases the developing bacteroids lack sufficient energyyielding substrates, and the infection threads of newly invaded cells are seen to develop large expansions and extrusions, which finally fill up the whole cell, crushing the nucleus into one corner. In the case of the TI/D-his ${ }^{\mathrm{r}}$ - 5 nodules, carbohydrate is plentiful, but cannot be used by the bacteria because of the induced $\mathrm{N}$-deficiency caused by the riboflavin deficit. Thus symptoms similar to carbohydrate starvation have developed in the newly invaded cells of older nodules. The polysaccharide which usually surrounds the rhizobia as they are released from the infection thread as a compact mass becomes more loosely structured. Relief of this situation with added riboflavin would therefore take some time, so that the number of rhizobia released into newly differentiated cells after late addition of riboflavin would not be as great as the number normally released per cell in TI nodules.

Root nodules of legumes are known to be rich in other B-group vitamins as well as riboflavin (Shemakhanova \& Bun'ko, I969). These authors have also shown that nodules formed by effective rhizobia contain significantly more riboflavin and cobalamin than those formed by ineffective strains, and that effective strains produce more riboflavin and free pyridoxine in pure culture. Although this emphasizes a possible link between the nutritional independance of a rhizobial strain and its performance as a symbiont, the role of the host in providing such compounds must also be considered. The riboflavin auxotroph is ineffective or partially effective on some cultivars, and almost fully effective on others (Schwinghamer, 1970). In each case where a block in the symbiosis occurs it can be corrected by the addition of riboflavin, suggesting that the cultivars differ significantly in either the amount or availability of riboflavin in their tissues. If this indeed proves to be the case (currently under investigation), it could mean that differences in the availability of other vitamins or related compounds within the host contribute to host specificity in the development of an effective symbiosis.

The authors wish to thank Mr M. L. Dudzinski for statistical analyses. One of us (C.E.P.) is grateful to the Department of Scientific and Industrial Research, New Zealand, for the provision of overseas leave, to the Australian National University for a research scholarship and to the Commonwealth Scientific and Industrial Research Organization for providing research facilities. 


\section{REFERENCES}

APPLEBY, C. A. (1967). Electron transport systems of Rhizobium japonicum, I. Haemoprotein P-450, other co-reactive pigments, cytochromes and oxidases in bacteroids from $\mathrm{N}_{2}$-fixing root nodules. Biochimica et biophysica acta $\mathbf{1 2}, 7 \mathrm{I}-87$.

Appleby, C. A. \& Bergensen, F. J. (1958). Cytochromes of Rhizobium. Nature, London 182, 174.

Bergersen, F. J. (1955). The cytology of bacteroids from root nodules of subterranean clover (Trifolium subterraneum L.). Journal of General Microbiology 13, 4I I-4I9.

BERGERSEN, F. J. (1970). The quantitative relationship between nitrogen fixation and the acetylene-reduction assay. Australian Journal of Biological Sciences 23, 1015-1025.

Bergersen, F. J. \& Briggs, M. J. (I958). Studies on the bacterial component of soybean root nodules: cytology and organization in the host tissue. Journal of General Microbiology 19, 482-490.

Brenchley, W. E. \& Thornton, H. G. (I925). The relation between the development, structure and functioning of the nodules on Vicia faba, as influenced by the presence or absence of boron in the nutrient medium. Proceedings of the Royal Society of London B 98, 373-399.

Dart, P. J. \& Mercer, F. V. (1963). Development of the bacteroid in the root nodules of barrel medic (Medicago tribuloides Desr.) and subterraneum clover (Trifolium subterraneum L.). Archiv für Mikrobiologie 46, 382-40I.

DART, P. J. \& Mercer, F. V. (1964). Fine structure changes in the development of nodules of Trifolium subterraneum L., and Medicago tribuloides Desr. Archiv für Mikrobiologie 49, 209-235.

Dixon, R. O. D. (1967). The origin of the membrane envelope surrounding the bacteria and bacteroids and the presence of glycogen in clover root nodules. Archiv für Mikrobiologie 56, 156-166.

Fahraeus, G. \& LuUnggren, H. (1968). Pre-infection phases of the legume symbiosis. The Ecology of Soil Bacteria. An International Symposium, pp. 396-421. Liverpool: University Press.

FotTrell, P. F. (1966). Dehydrogenase isoenzymes from legume root nodules. Nature, London 210, 198-199.

Goodchild, D. J. \& Bergersen, F. J. (1966). Electron microscopy of the infection and subsequent development of soybean nodule cells. Journal of Bacteriology 92, 204-2 13.

Huber, J. D., Parker, F. \& Odland, G. F. (1968). A basic fuchsin and alkalinized methylene blue rapid stain for epoxy-embedded tissue. Stain Technology 43, 83-87.

Mosse, B. (1964). Electron microscope studies of nodule development in some clover species. Journal of General Microbiology 36, 49-66.

Moustafa, E. \& Greenwoon, R. M. (1967). Esterase and phosphatase isoenzymes in rhizobial bacteroids in relation to strain effectiveness and proportion of nodule tissue in Lotus. New Zealand Journal of Science ro, 548-555.

Roughley, R. J., DaRT, P. J. \& Nutman, P. S. (1970). The infection of Trifolium subterraneum root-hairs by Rhizobium trifolii. Journal of Experimental Botany 2r, I86-194.

SChwinghamer, E. A. (1960). Studies on induced variation in the rhizobia. I. Defined media and nodulation test techniques. Journal of Applied Microbiology 8, 349-352.

SChwinghamer, E. A. (1967). Loss of effectiveness and infectivity in mutants of Rhizobium resistant to metabolic inhibitors. Canadian Journal of Microbiology 14, 355-367.

SCHWINGHAMER, E. A. (I969). Mutation to auxotrophy and prototrophy as related to symbiotic effectiveness in Rhizobium leguminosarum and $R$. trifolii. Canadian Journal of Microbiology 15, 611-622.

SCHWINGHAMER, E. A. (1970). Requirement for riboflavin for effective symbiosis on clover by an auxotrophic mutant strain of Rhizobium trifolii. Australian Journal of Biological Sciences 23, I 187-I 196.

Shemakhanova, N. M. \& Bun'ko, I. P. (1969). Activity criteria for the nodule bacteria of beans. Mikrobiologiya $\mathbf{3 8 , 1 0 7 0 - 1 0 7 4 .}$

Thornton, H. G. (1930). The influence of the host plant in inducing parasitism in lucerne and clover nodules. Proceedings of the Royal Society of London B ro6, I IO-I22.

TuZimura, K. (1950). Lactoflavin in the root-nodules of leguminous plants. Journal of the Agricultural Chemistry Society of Japan 24, 97-100.

Williams, C. H. \& Twine, J. R. (1967). Determination of nitrogen, sulphur, phosphorus, potassium, sodium, calcium, and magnesium in plant material by automatic analysis. Technical Papers, Division of Plant Industry, C.S.I.R.O., Australia, no. 24.

Wong, P., Evans, H. J., Klucas, R. P. Russell, S. (1972). Investigations into the pathway of electron transport to the nitrogenase from nodule bacteroids. Plant and Soil (in the press).

Yao, Phaik Y. \& VinCENT, J. M. (I968). Host specificity in the root-hair 'curling factor' of Rhizobium spp. Australian Journal of Biological Sciences 22, 413-423. 